WwW.ijbpas.com

\title{
CROP COMBINATION OF SANGLI DISTRICT (MAHARASHTRA)
}

\section{KAMBLE DS $^{1^{*}}$ AND SHAHAPURKAR OV}

1: Assistant Professor, Department of Geography, Jawahar Arts, Science \& Commerce College, Andur, Dist .Osmanabad, Maharashtra, India

2: Head, Professor \& Research Guide, Department of Geography, Rajarshi Shahu Mahavidyalaya (Autonomous), Latur. Maharashtra, India

"Corresponding Author: Dayanand S. Kamble: E Mail: kambleds19@gmail.com

Received $10^{\text {th }}$ June 2021; Revised 11 ${ }^{\text {th }}$ July 2021; Accepted 20 ${ }^{\text {th }}$ Aug. 2021; Available online 15 ${ }^{\text {th }}$ Jan. 2022

\section{https://doi.org/10.31032/IJBPAS/2022/11.1.1079}

\begin{abstract}
The Concept of Crop Combination is a scientific device to study the existing relationship of crops in association with each other, The pattern of crop combination gives spatial predominance of specific crops or combination, resulting in the emergence of crop areas, However, it is evident that the higher number of crops in combination. The crops are combination in the field due to the erratic nature of rainfall and insufficient irrigation. The study of forms an integral crop combination part of agricultural geography.
\end{abstract}

\section{Keyword: Crop Combination, cultivation, infrastructure}

\section{INTRODUCTION:}

India is an essentially agricultural country. In development country like India crops generally grown in combination. The study of crop combination of any region has gained importance in the geographical study .An important aspect of agricultural geography as it provides a good basis for agricultural regionalization is the study of crop combination. The crops are generally grown in combinations and it is really that a particular crop occupies a position of total isolation other crops in a given area unit at a given point of time. The distribution maps of individual crops are interesting and useful for planners but it is even more important to view the integrated 
assemblage of the various crops grown in an arial unit. For a comprehensive and clear understanding of the agricultural mosaic of an agro climatic region and for the planning and development of its agriculture, a systematic study of crop combinations is of great significance. The study of crop combination thus forms and integral part of agricultural geography and such study is significantly helpful for district agricultural planning.

Study Area:
The Sangli district is situated in southran part of Maharashtra state and is a part of Deccan plateau. It situated between the latitudes $16^{0} 45^{\prime}$ 'north and $17^{0} 33$ 'north and longitudinal of $73^{\circ} 42^{\prime}$ east and $75^{\circ} 40^{\prime}$ east. The district is bounded by Satara and Solapur district on the north western side. Southern is boarded by Belgaum and Bijapur district of Karnataka State at the centers and east Kolhapur district and the Ratnagiri district to the west.

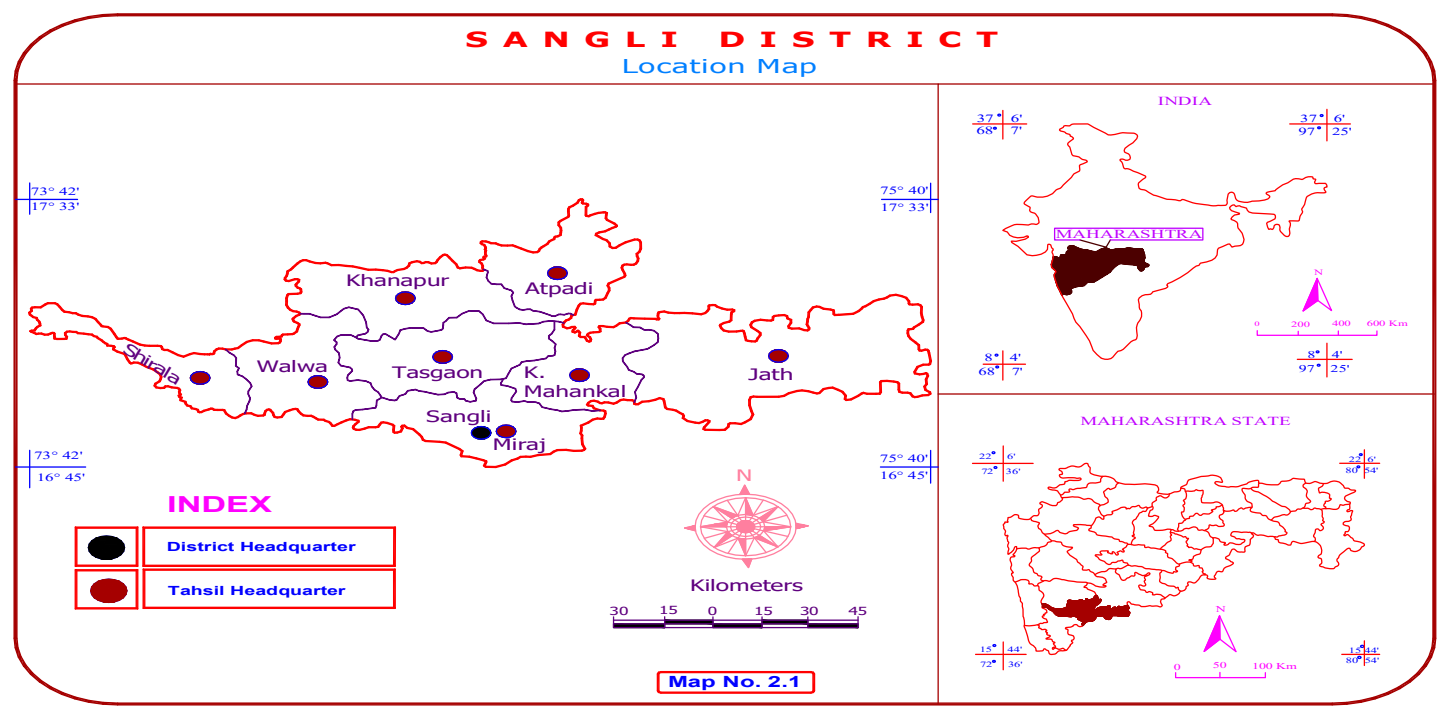

The east-west length of Sangli district is about $205 \mathrm{~km}$ and south-north width of the district is about $96 \mathrm{~km}$. The area of the districtis 8572.00 square kilometers and it is $21^{\text {st }}$ highest geographical area in Maharashtra state. It is at a heightof553meter from normal Sea level. According to 2011 census there are 724 villages in Sangli District. There are 705 Grampanchayat and 10 Panchayat Samiti in the District.

\section{Objectives:}

The Present Study has been undertaken with fallowing Specific Objectives:

1) To study Crop Combination in the study area.

2) To find out the transformation in Crop Combination in the Sangli District for the year $1990-95$ to $2010-15$.

Data Base and Research Methodology:

The present research is based on secondary 
data collected from Directorate of economics and District statistical information state Economic Review in Sangli District. The Data has been collected from 1990-95 to2010- 15 .

\section{Crop Combination:}

The crop combination region delineated would emphasis the regional frame work of agricultural activities and specialization of crops in the area. The pattern of crop combination regions that will emerge from the delineation might also serve the meaningful purpose in a balanced regional agricultural planning different approaches have been applied for the delineation of crop combination. The combination analysis was originally introduced in geographical research by weaver in his outstanding study of crop combination of Mid-Western United States.

For the present study an attempt is made to delineate the crop combination regions by applying crop combination method i.e. Minimum standard deviation method is introduced by weaver (1954) and Doi's method.

"The study of crop combination regions constitutes important aspects of agricultural geography as it provides a good basis for agricultural regionalization (Majid Husain, 2007)" out of many methods of crop combination the method used by weaver, john C. 1954 and Doi's have been used for the tahsil wise crop combination of Sangli district from 1990-95 and 2010-15. For the present study an attempt is made to delineate the crop combination regions by applying minimum standard deviation method as introduced by Doi(1959)

\section{Crop combination According to Doi's method:}

A modified form of Weaver's technique has been put forward by Doi (1959), which was considered to be the easiest for combination analysis till the computer programming facilities made the task to tedious calculations for deviation analysis easy and simple. The modified format of Doi's technique solves the problems of Weaver's technique simultaneously by substituting the variance $\left(\Sigma \mathrm{d}^{2} / \mathrm{n}\right)$ of Weaver with the sum of squared deviations $\left(\Sigma \mathrm{d}^{2}\right)$. The combination having the lowest $\Sigma \mathrm{d}^{2}$ will is the crop combination. In Doi's technique it is not required to calculate $\Sigma \mathrm{d}^{2}$ for each combination but the crop combination is actually established by consulting one-sheet table which presents critical values for various elements at different ranks against cumulative percentage of elements at higher ranks; for an agricultural geographer elements here mean crops, livestock or enterprises. The use of one-sheet table requires only the summing up of actual percentages under different crops instead of 
finding the differences between actual demonstrated by making use of actual percentages and theoretical distributions. percentages under different crops in the Sangli

The use of Doi's one-sheet table can be district for the year 2010-15.

Table No. 1.1: Crop Combination Region by Doi's Method

\begin{tabular}{|c|c|c|c|c|c|c|c|}
\hline $\begin{array}{c}\text { Name of the } \\
\text { Tahsil }\end{array}$ & Year & Two Crop & Three Crop & Four Crop & Five Crop & Six Crop & Seven Crop \\
\hline \multirow[t]{2}{*}{ Shirala } & $1990-95$ & & & $\begin{array}{c}\text { Fo+R+J } \\
+\mathbf{G n}\end{array}$ & & & \\
\hline & $2010-15$ & & & & & & $\begin{array}{c}\mathbf{R}+\mathbf{S}+\mathbf{J}+\mathbf{G n}+ \\
\mathbf{M}+\mathbf{F o}+\mathbf{W}\end{array}$ \\
\hline \multirow[t]{2}{*}{ Walwa } & $1990-95$ & & & $\begin{array}{c}\mathbf{O o}+\mathbf{J}+\mathbf{S} \\
+\mathbf{G n}\end{array}$ & & & \\
\hline & $2010-15$ & & & & & & $\begin{array}{c}\mathbf{S}+\mathbf{J}+\mathbf{G n}+\mathbf{F o} \\
+\mathbf{G r}+\mathbf{R}+\mathbf{W}\end{array}$ \\
\hline \multirow[t]{2}{*}{ Khanapur } & $1990-95$ & & & $\begin{array}{c}\mathbf{J}+\mathbf{B r}+\mathbf{O} \\
\mathbf{p}+\mathbf{G n}\end{array}$ & & & $\begin{array}{c}\mathbf{J}+\mathbf{G n}+\mathbf{B r}+\mathbf{O p} \\
+\mathbf{S}+\mathbf{W}+\mathbf{F o}\end{array}$ \\
\hline & 2010-15 & & & & & & \\
\hline \multirow[b]{2}{*}{ Atpadi } & 1990-95 & $\mathbf{J}+\mathbf{B r}$ & & & & & \\
\hline & 2010-15 & $\mathbf{J}+\mathbf{B r}$ & & & & & \\
\hline \multirow[b]{2}{*}{ Tasgaon } & 1990-95 & & $\mathbf{J}+\mathbf{S}+\mathbf{G n}$ & & & & \\
\hline & 2010-15 & & $\mathbf{J}+\mathbf{G r}+\mathbf{W}$ & & & & \\
\hline \multirow[t]{2}{*}{ Miraj } & $1990-95$ & & & & & $\begin{array}{l}\mathbf{J}+\mathbf{O o}+\mathbf{S}+ \\
\mathbf{B r}+\mathbf{G n}+\mathbf{w}\end{array}$ & \\
\hline & 2010-15 & & & & & $\begin{array}{c}\mathbf{J}+\mathbf{S}+\mathbf{B r}+\mathbf{G r} \\
+\mathbf{G n}+\mathbf{W}\end{array}$ & \\
\hline \multirow{2}{*}{$\begin{array}{c}\text { K. } \\
\text { Mahankal }\end{array}$} & 1990-95 & $\mathbf{J}+\mathbf{B r}$ & & & & & \\
\hline & 2010-15 & $\mathbf{J}+\mathbf{B r}$ & & & & & \\
\hline \multirow[b]{2}{*}{ Jat } & $1990-95$ & $\mathbf{J}+\mathbf{B r}$ & & & & & \\
\hline & 2010-15 & $\mathbf{J}+\mathbf{B r}$ & & & & & \\
\hline \multirow[b]{2}{*}{ Sangli District } & 1990-95 & & $\mathrm{J}+\mathrm{Br}+\mathrm{Oo}$ & & & & \\
\hline & 2010-15 & & & & & $\begin{array}{c}\mathbf{J}+\mathbf{S}+\mathbf{B r}+ \\
\mathbf{G n}+\mathbf{G r}+\mathbf{W}\end{array}$ & \\
\hline
\end{tabular}

Source: Compiled by the researcher. (Note: $J=J a w a r, B r=B a j a r a, R=R i c e, W=$ Wheat,$M=$ Maize, Gn=Groundnut,Gr=Gram,S=Sugar cane,Op=Other pulses, Oo =Other Oil Seeds, Fo=Fodder)

1. Monoculture: Monoculture is absent in study region.

\section{Two Crop Combinations:}

During 1990-95 as per Doi's method (1959) two crops combination is recorded in Atpadi, Kawate Mahakal and Jattahsils. In these tahsils,Jowar and Bajara crops association is recorded. During 2010-15, the two crops combination was observed in same tahsils as well as same crops in the entire study region.

\section{Three Crop Combinations:}

Three crop combinations are found only in Tasgaontahsil in the study region in the year 1990-95. In Tasgaontahsil, three crops entered in combination are Jowar, Sugarcane and Groundnut. In the year 2010-15, the three crops combinations was noticed in same tahsil, in the tahsil three crop combination are Jowar, Gram and Wheat. 


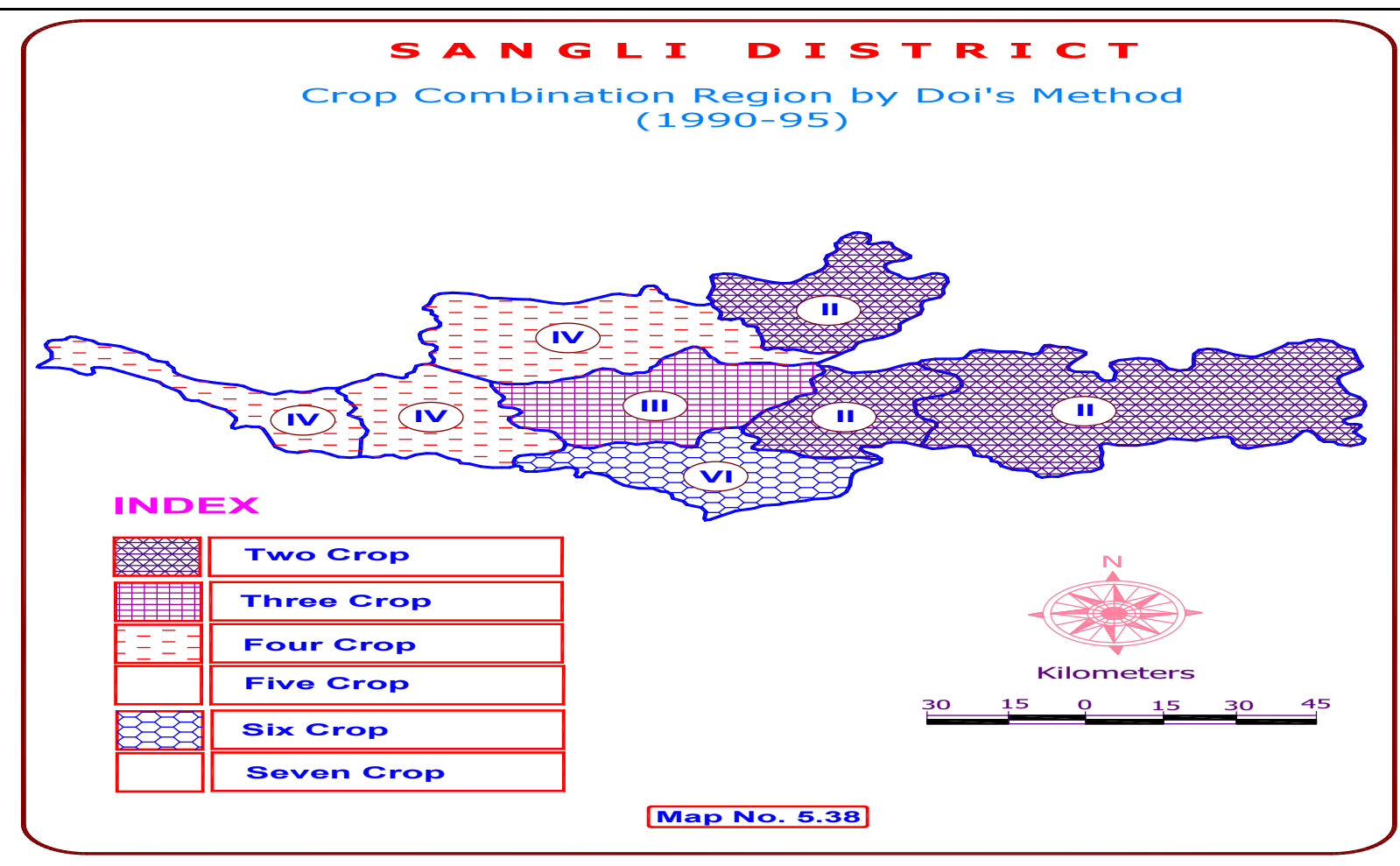

\section{Four Crop Combinations:}

Four crop combinations are recorded in three tahsils in the study region these are Shirala, Walwa and Khanapur tahsils in the year 199095. In Shiralatahsil crops entered in combination Fodder, Rice, Jowar and Groundnut. In Walwa tahsil like Other Oilseeds, Jowar, Sugarcane and Groundnut respectively whereas Khanapur tahsil Jowar, Bajara, Other Pulses and Groundnut association is registered during the period in 1990-95. During 2010-15, the four crops combination was absent throughout the region.

\section{Five Crop Combinations:}

During the study period, the five crop combination was absent throughout the region.

\section{Six Crop Combinations:}

Six crops combination is recorded only in Mirajtahsil in the study region in the year 1990-95. In Mirajtahsil, the association of Jowar, Other Oilseed, Sugarcane, Bajara, Groundnut and Wheat is found. In the year 2010-15, six crop combinations are recorded in same tahsil and there are Jowar, Sugarcane, Bajara, Gram, Groundnut and Wheat crops entered in crop combination. 


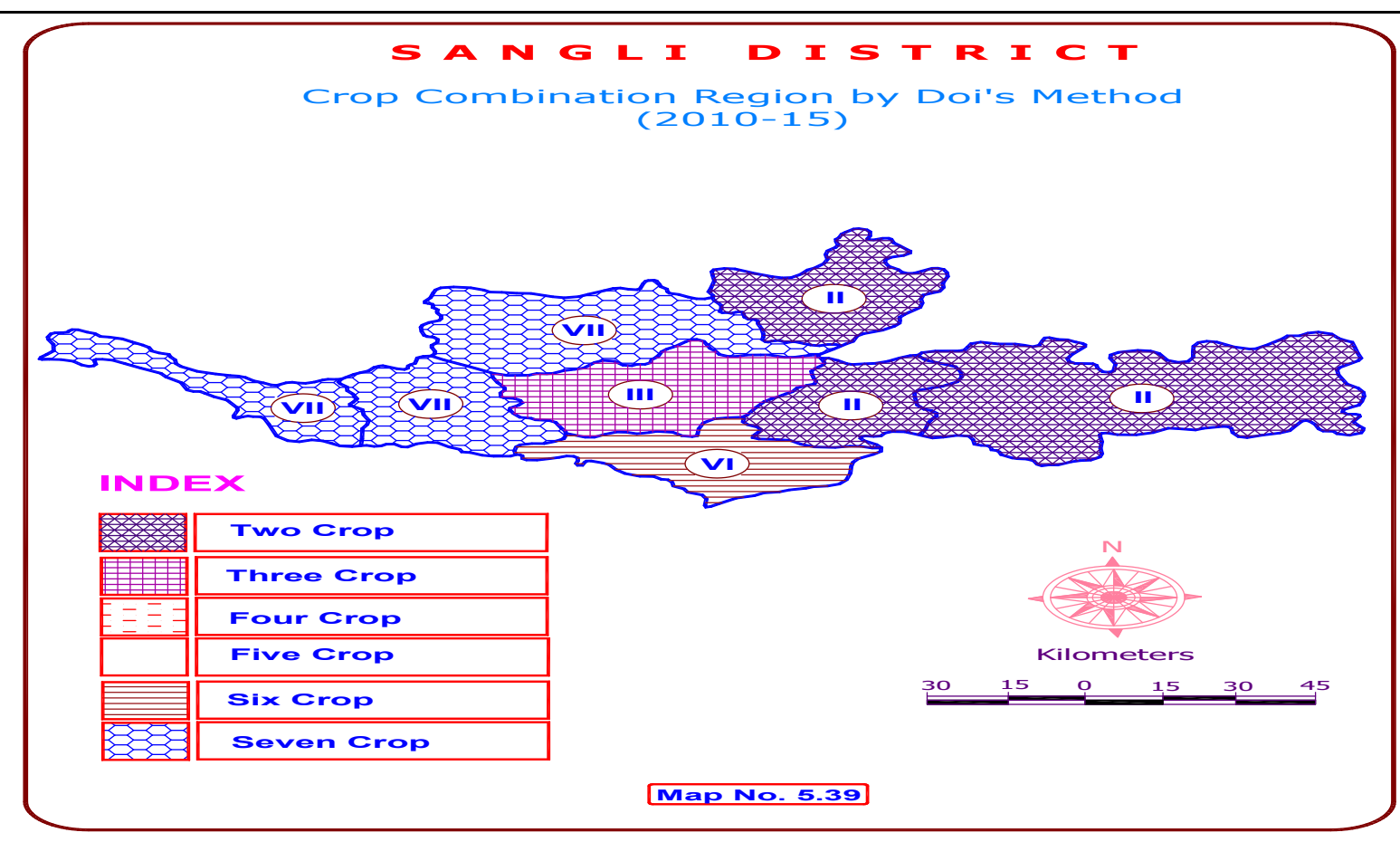

\section{Seven Crop Combinations:}

Seven crops combination is recorded only in Khanapurtahsil in the study region in the year 1990-95. In Khanapurtahsil the Jowar, Groundnut, Bajara, Other pulses, Sugarcane, Wheat and Fooder crops association is recorded. In the year 2010-15, seven crop combinations are recorded in two tahsils and these are Shirala and Walwatahsils. In Shiralatahsil, Rice, Sugarcane, Jowar, Groundnut, Maize, Fodder and Wheat crops entered in crop combination, whereas in Walwatahsil Sugarcane, Jowar, Groundnut, Fodder, Gram, Rice and Wheat association is registered.

The comparison between Map No. 6.38 and Map No.6.39 reveals the change in crop combination region based on Doi's method.
Three crops to six crops combination registered in Sangli region as whole during the period of investigation (1990-95 and 2010-15). Eight tahsils shows the change in crop combination i.e. Shirala, Walwa, Khanapur, Atpadi, Tasgaon, Miraj, Kawate Mahakal and Jat. Two crops to three crops change is recorded in Tasgaontahsil; Three crops to four crops change is recorded in Shirala, Walwa, Khanapurtahsils, four crops to seven crops is in Shirala and Khanapurtahsils in the crops combination pattern during the period of investigation according to Doi's method.

\section{CONCLUSION:}

During 1990-95 as per Doi's method (1959) two crops combination is recorded in Atpadi, Kawate Mahakal and Jat tahsils. In these tahsils, Jowar and Bajara crops 
association is recorded. During 2010-15, the two crops combination was observed in same tahsils as well as same crops in the entire study region.

In crop combination region based on maximum deviation method, One tahsil, i.e. Atpadi was recorded the changes in crop association pattern, two to one change observed. There is no change in number of crops in the association pattern in remaining tahsils, during the period of under review.

\section{REFERENCES:}

[1] Ahmed A. and Siddiqui M.F. (1967): "Crop Combination Pattern in Luni Basins', Geographer (M.U.A.) Vol. XIV.pp.69-80.

[2] Weaver John C. (1954), “Crop Combination Regions in the Middle West',, The Geographical Review 44(1954), pp.175-2000.

[3] Johnson B.L.C. (1958): Crop Association Regions in East Pakistan, Geography. Vol. 43, pp.86-103.

[4] Rafiullah S. M. (1956): “A New Approach to Functional Classification of Towns', Geographer Vol. 8. pp. 40-53.

[5] Husain M. (2014): Systematic Agricultural Geography, Rawat Publications. Jaipur.

[6] Doi K. (1957), “The Industrial
Structure of Japanese Prefecture,' Proceedings I. G. U. Regional Conference in Japan, pp. 310. 316.

[7] Socio-Economic Abstract of Sangli District.

[8] www.google.com

[9] C.M. Thakar, S.S. Parkhe, A. Jain etal., 3d Printing: Basic principles and applications, Materials Today: Proceedings, https://doi.org/10.1016/j. matpr.2021.06.272

[10] Khan, R. M. I., Kumar, T., Supriyatno, T., \& Nukapangu, V. (2021). The Phenomenon of ArabicEnglish Translation of Foreign Language Classes During The Pandemic. IjazArabi Journal of Arabic Learning, 4(3). https://doi.org/10.18860/ijazarabi.v4i

\section{$\underline{3.13597}$}

[11] Sajja, G., Mustafa, M., Phasinam, K., Kaliyaperumal, K., Ventayen, R., \&amp; Kassanuk, T. (2021). Towards Application of Machine Learning in Classification and Prediction of Heart Disease. 2021 Second International Conference On Electronics And Sustainable Communication Systems (ICESC).

https://doi.org/10.1109/icesc51422.20 $\underline{21.9532940}$ 
[12] Veluri, R., Patra, I., Naved, M., Prasad, V., Arcinas, M., Beram, S., \&; Raghuvanshi, A. (2021). Learning analytics using deep learning techniques for efficiently managing educational institutes. Materials Today: Proceedings.

https://doi.org/10.1016/j.matpr.2021.1 $\underline{1.416}$ 